\title{
Reconstructing Antiquity in the 1770s: The Decoration of Pliny the Younger's Villa Maritima in Count Stanislaus K. Potocki’s Vision
}

\author{
JERZY MiZIOŁEK
}

The only way for us to become great or, if this be possible, inimitable, is to imitate the ancients. ${ }^{1}$

Count Stanislaus Kostka Potocki (1755-1821) is at once the Polish equivalent to J. J. Winckelmann and the Lord Burlington of his country. ${ }^{2}$ His translation of the Geschichte der Kunst des Altertums (The Art of the Ancients or The Polish Winckelmann) and his other writings provided valuable groundwork for the development of scientific archaeology and art history in Poland. ${ }^{3}$ Until today the Count has been known outside his native country almost exclusively through the life-sized equestrian portrait of him painted by Jacques-Louis David in 1780$1781{ }^{4}$ Though, his numerous achievements include at least two others which are of international importance: his Lettre d'un étranger sur le Salon de 1787 and, more notably, his reconstruction on paper of Pliny the Younger's villa at Laurentum (hence called Laurentina), some twenty kilometres from Rome. The reconstruction is based on Pliny's famous letter To Gallus, but was to some degree also influenced by Winckelmann. Potocki's study of the letter resulted in over thirty large colour drawings $(57.7 \times 89.5 \mathrm{~cm})$ being executed in Rome, in the years 1777 and 1778 , by a group of artists under Potocki's supervision. ${ }^{6}$

1 Winckelmann (1987), 5.

2 The latter expression is to be found in Ruffière du Prey (1994), 148.

3 Potocki most probably translated Winckelmann's book in the 1780 s but only published it in 1815 , see Miziołek (2006), 25-42 with earlier bibliography.

4 Ryszkiewicz (1973), 77-95.

5 See Potocki (1787), a copy of this rare publication is preserved in The Czartoryski Library in Kraków. See also Żmijewska (1977), 344-353.

6 All of them are reproduced in Ruffière du Prey (1994), 148 ff., and in Miziołek (2007).

An English version of this publication is in preparation. It is the result of collaboration with $\mathrm{M}$. Tarkowski and M. Baliszewski. 
Among them were two Italians - Giuseppe Manocchi (d. 1782) and Vincenzo Brenna (1747-1818) and a Pole - Franciszek Smuglewicz (1745-1807), who lived in Rome from 1763 to 1784 . $^{7}$ During the nineteenth century the drawings were mounted in two large albums, one entitled Villa de Pline le jeune dite Laurentina, and the other, Intérieure de la Villa de Pline le jeune par Brenna. In the late 1790s, Count Potocki produced a twenty-four-page manuscript titled Notes et Idées sur la Villa de Pline which was intended to serve as a commentary to the drawings. ${ }^{8}$ The commentary has remained unpublished to this day.

In the 1940s the late Stanislaus Lorentz conducted preliminarily research on the thirty-six drawings assembled in the two albums; and in the 1990s a more in-depth examination was carried out by Pierre de la Ruffinière du Prey. However, the issue of the villa's interior decoration, with its paintings, sculptures and mosaics, is still to be researched.

The author has already published a survey on this subject in English, as well as a book in Polish, which is a catalogue to an exhibition held at the National Library at Warsaw. The catalogue contains all the drawings from the two albums and a Polish translation of the Notes et Idées sur la Villa de Pline. ${ }^{9}$ In both publications the author argues that the best drawings reconstructing the Laurentina were executed by the little known artist Manocchi; and that Potocki's restitution of Pliny's villa included only thirty-one drawings not thirty-six..$^{10}$ The remaining five were executed for other sites to be reconstructed. On the occasion of the exhibition - thanks to the 3D Studio Max 8, which offers advanced possibilities for the work with three-dimensional models - Count Potocki's reconstruction was re-created virtually. ${ }^{11}$

This paper, however, is concerned mainly with the interior decoration of the villa, with its statues and paintings, all of which are adaptations or composites of ancient masterpieces known to the eighteenth century.

7 For Brenna see Tedeschi (2007), 405-419; for all three artists see Miziołek (2006), 26, with bibliography.

8 An English translation of this text by Jane M. Todd, made thanks to the Getty Research Institute in Spring 2006, was published in Miziołek (2006), 33-37. Some fragments are cited by Ruffière du Prey (1994), 148, 163. All citations from the Notes in the present paper are from Todd's translation.

9 See Miziołek (2006) and Miziołek (2007).

10 For Manocchi, a little studied Italian artist who also worked for Robert Adam, see Miziołek (2006), 25-33. See also Stillman (1966), 42-43, 54. Numerous drawings, once in the collection of Robert Adam are now in the Sir John Soane's Museum in London; some of them are reproduced in Miziołek (2007), Figs. 54-57, 94, 99 and 104. His other numerous drawings, as yet unpublished, are housed at the Hermitage State Museum, St. Petersburg. Thanks to Valerij Shevchenko I could examine them in October 2008. A beautiful example for Manocchi's drawing skills is being preserved in by the Staatliche Museen zu Berlin, Kunstbibliothek. See Evers (2007), 168-169.

11 Tarkowski/Baliszewski (2006), 53-55. 


\section{Potocki's vision of the villa at Laurentum as described in his Notes et}

\section{Idées sur la Villa de Pline}

In the years 1772 to 1774 , Count Potocki studied architecture, literature and history at the Royal Academy in Turin. ${ }^{12}$ From November 1774 to October 1775 he went on a Grand Tour, to visit Italy's cultural centres: first and foremost Rome, Naples and the Bay of Naples. ${ }^{13}$ While in Rome he met Giovanni B. Piranesi and Baron Johann F. Reiffenstein. Among other archaeological sites he visited the Domus Aurea where Smuglewicz and Brenna were working on drawings for Ludovico Mirri's album Vestigia delle Terme di Tito e loro interne pitture, published in $1776 .{ }^{14}$ It may have been in Turin or in Rome that the Count came to know about Pliny's villa maritima and Winckelmann's plan to publish a book about it. ${ }^{15}$ In the Notes he says:

The house described by Pliny in this letter [To Gallus] takes its name from Laurentium, a place inhabited and beautified by the Romans, of which only the most insignificant traces remain today. A wretched tavern known as Saint Lorenzo occupies part of the site of the former Laurentium. Not far from there, on the dependencies of the Sacchetti villa, the ruins of Pliny's villa were discovered in 1714. [...] not far from Ostia and close to the mouth of the Tiber, from among whose ruins (according to Winckelmann) precious marble, beautiful mosaics, and a few busts of the greatest beauty, such as that of Lucius Verus, were extracted. ${ }^{16}$

Interestingly, the ruins of the spacious villa (the so-called Palombara) - now hidden among trees and bushes - have a characteristically large peristylium (cavaedium) as well as a cryptoporticus close to it. ${ }^{17}$ A similar cryptoporticus and equally large peristylium can be found in the drawings depicting Potocki's vision of the Laurentina (fig. 1). Thus, there is no doubt that both eighteenthcentury archaeology and in-depth reading of Pliny the Younger's letters paved the way for the idealised reconstruction of the villa on paper.

12 No biography has been written on the Count, see Ruffinière du Prey (1994), 148 ff.; Grand Tour (2006) with texts by P. Jaskanis, A. Rottermund, A. Kwiatkowska, A. Ekielska-Mardal, passim and s.v. Bentkowska (1996), 364. See also the recently published volume Archeologia, letteratura, collezionismo (2008), passim.

13 Grand Tour (2006), 23-71.

14 See also Carletti (1776) being a commentary on the murals published by Mirri. See also Pinot de Villechénon (2002). The earlier exploration of the Domus Aurea by Charles Cameron is discussed in Salmon (1993), 69-93.

15 Winckelmann (2006), 74, 343; Winckelmann also refers to the villa in three letters, one of which was sent to Clérisseau at the end of 1767, see Winckelmann (1956), 345.

16 See Winckelmann (2006), 74, 343 and Winckelmann (1956), 345. It may be deduced from this that he planned to publish a book on the Laurentina.

17 The remnants of the villa at Castelporziano (Castel Fusano) are discussed in Lanciani (1903), 241ff. and Ramieri (1995), 407-416. 


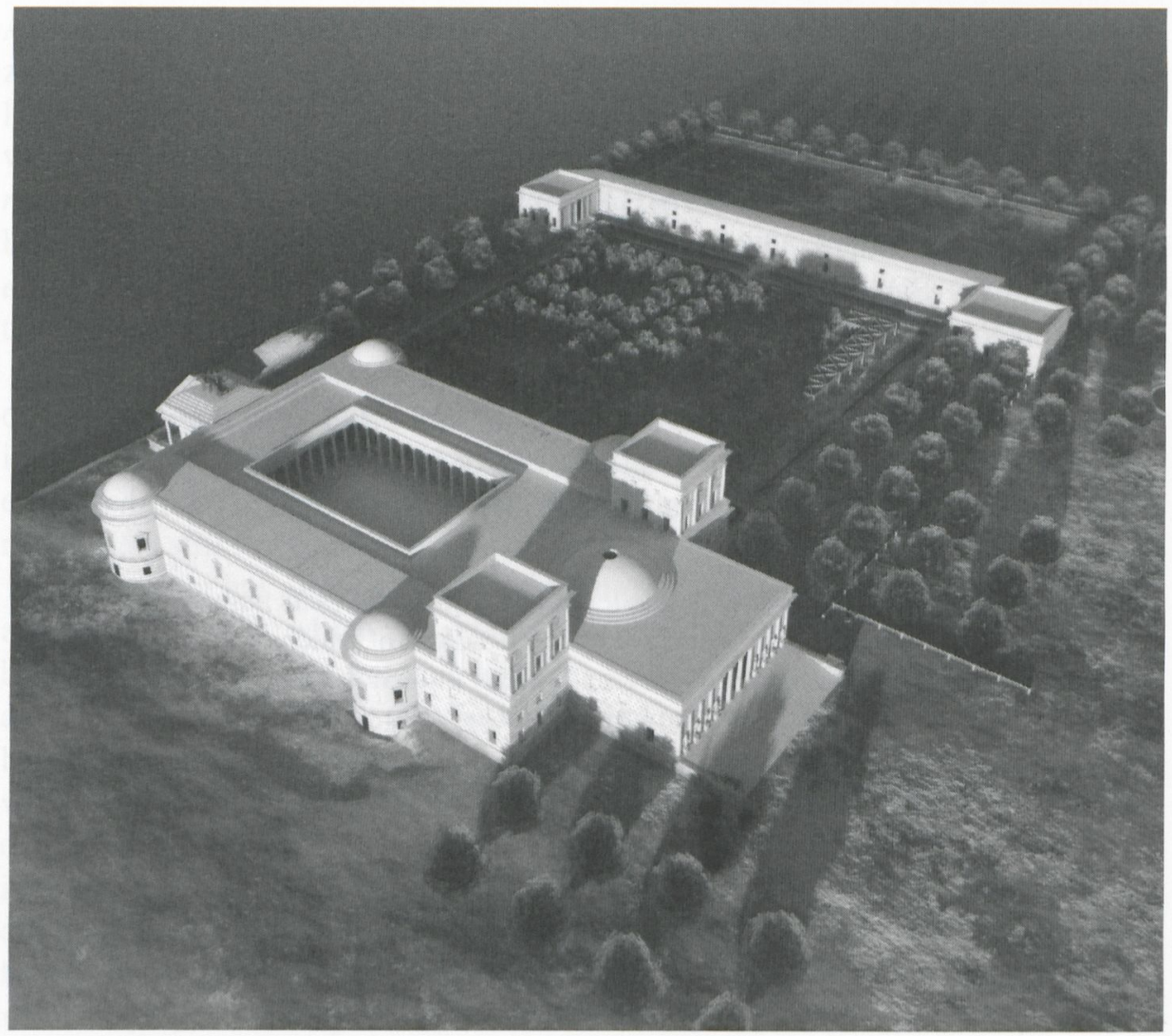

Fig. 1 3D reconstruction of Stanislaus K. Potocki's Laurentine Villa

Beginning in the early-Renaissance, art lovers and architects would read Pliny's letter when in need of inspiration for their own villa projects. ${ }^{18}$ Architects such as Vincenzo Scamozzi (1615), Jean-François Félibien (1695), Robert Castell (1728) and Friedrich Krubsacius (1760), created reconstructions of Pliny's villa and the surrounding gardens on paper. ${ }^{19}$ All of them were led by their imagination while reading rather than by examining the relics of Antiquity. Potocki chose a somewhat different approach, though his ground plan of the Laurentina, as already noticed by Ruffinière du Prey, is similar to that by Scamozzi and Felibien. Furthermore, his vision of the façade facing the sea resembles Renaissance or Neoclassical designs reminiscent of Palladio. The sec-

18 See Wenzel (2006).

19 All these reconstructions are discussed by Culot/Pinon (1982); See also Tanzer (1924) and Förtsch (1993). 
ond part of the Notes provides insight about the villa's architecture and interior decoration. Potocki writes:

I attempt to base myself on all the most interesting things it [antiquity] offered me. The Pantheon, the Temple of Jupiter Tonans, the Colosseum, the Emperors' Palace, became my architecture books from which I drew the most beautiful proportions from the orders known to us. Herculaneum, Pompeii, the Bay of Naples, Pozzuoli, the Baths of Titus, and so many other monuments scattered throughout Rome and its environs were of no small aid both in the choice of ancient paintings, ornaments, and mosaics and in the form of the rooms, whose plans I scrupulously followed. So it is that in gathering together the most beautiful remains of Roman architecture and embellishing Pliny's villa with them, I thought I could do justice to the pure taste of the century of Trajan. ${ }^{20}$

Further on, he adds: »That manner of unveiling antiquity, however imperfect it might be, seemed to me the surest and the most simple.« Potocki then writes about »the creative genius of Greece «, »the grandeur and boldness of the Romans « and the »sublime simplicity of the ancient«. These expressions immediately bring to mind Winckelmann's Reflections on the Imitation of Greek Works in Painting and Sculpture and A History of the Art in Antiquity. ${ }^{21}$

\section{The decoration of the cryptoporticus with its heliocaminus}

One best starts into the investigation of Potocki's reinvention of antiquity with the villa's cryptoporticus. In his letter to Gallus, Pliny writes that it is »almost like a public building «, with a strolling area in front of it »scented with violets $\ll^{22}$. He then goes on to say: Over beyond the strolling area, the passageway, and the garden is my favourite suite of rooms, truly my favourite, for I had it built myself. It contains a sun-room [heliocaminus], which looks out on the strolling area on one side, and on the sea on the other, and it gets the sun on both. ${ }^{23}$ Potocki imagined that the cryptoporticus was adorned with beautiful fresco decorations of the grotesque type, covering both the walls and the ceiling. In the upper section of the reconstruction drawing, a beautiful semicircular structure with a coffered apse which was to face the sea is presented (fig. 2). Above the apse are two Victories paying shomage $<$ to a seven-piped syrinx, or panpipes in a wreath, while below there is an all'antica bench with a relief above it depicting four

20 It is unclear whether Potocki had in mind the Domus Aurea or the Palace of Diocletian in Split.

21 Winckelmann (1987), 33-41 and passim; see also Potts (1994), 113ff.

22 Pliny the Younger, Letters, XVII, 16-17; The translator notes that »Pliny is not making extravagant claims about its dimensions, but merely draws attention to it as an unusual feature in domestic architecture«. Pliny the Younger (2006), 307. 


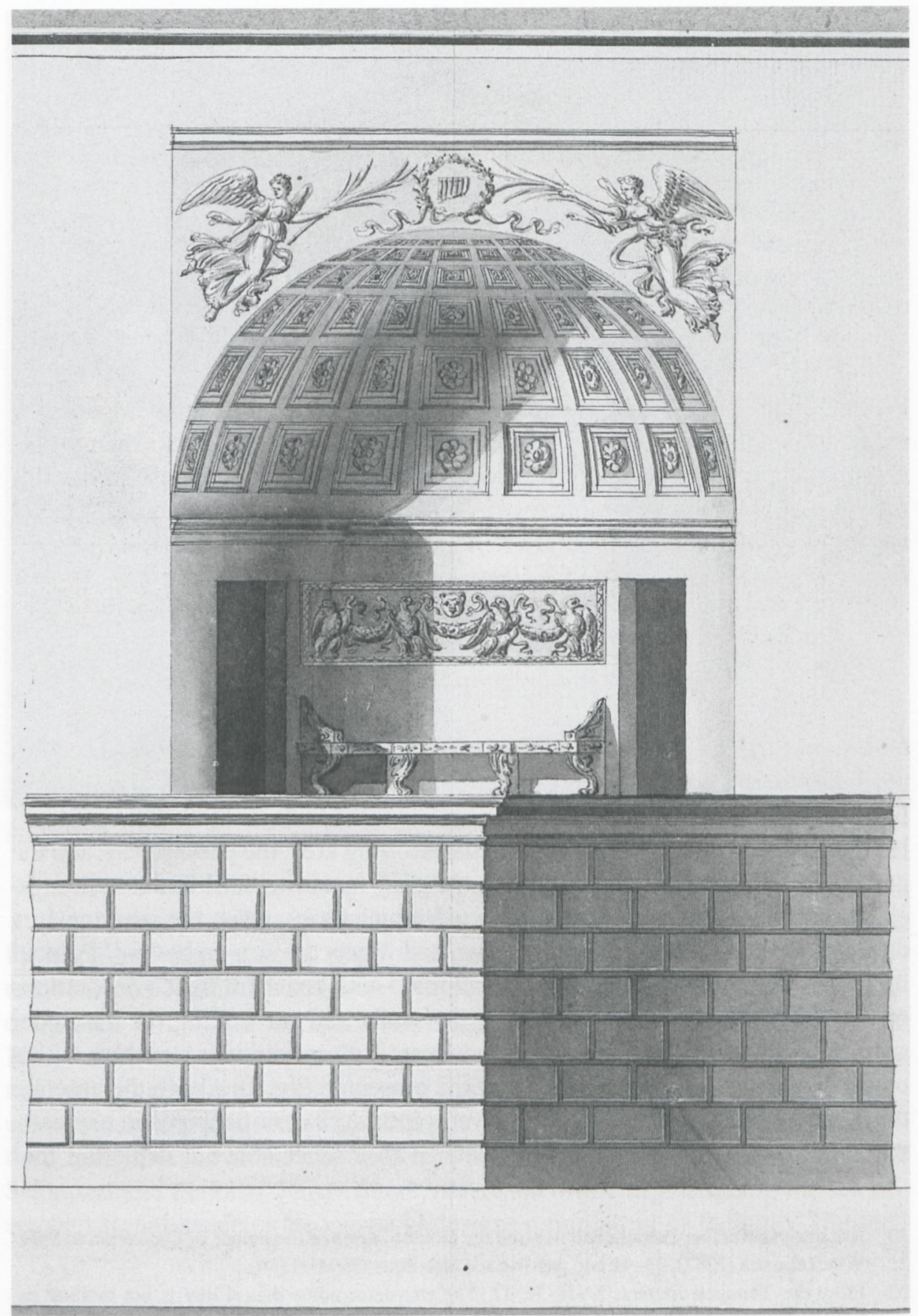

Fig. 2 Stanislaus K. Potocki, Vincenzo Brenna, Heliocaminus, coloured drawing, Warsaw, National Library 


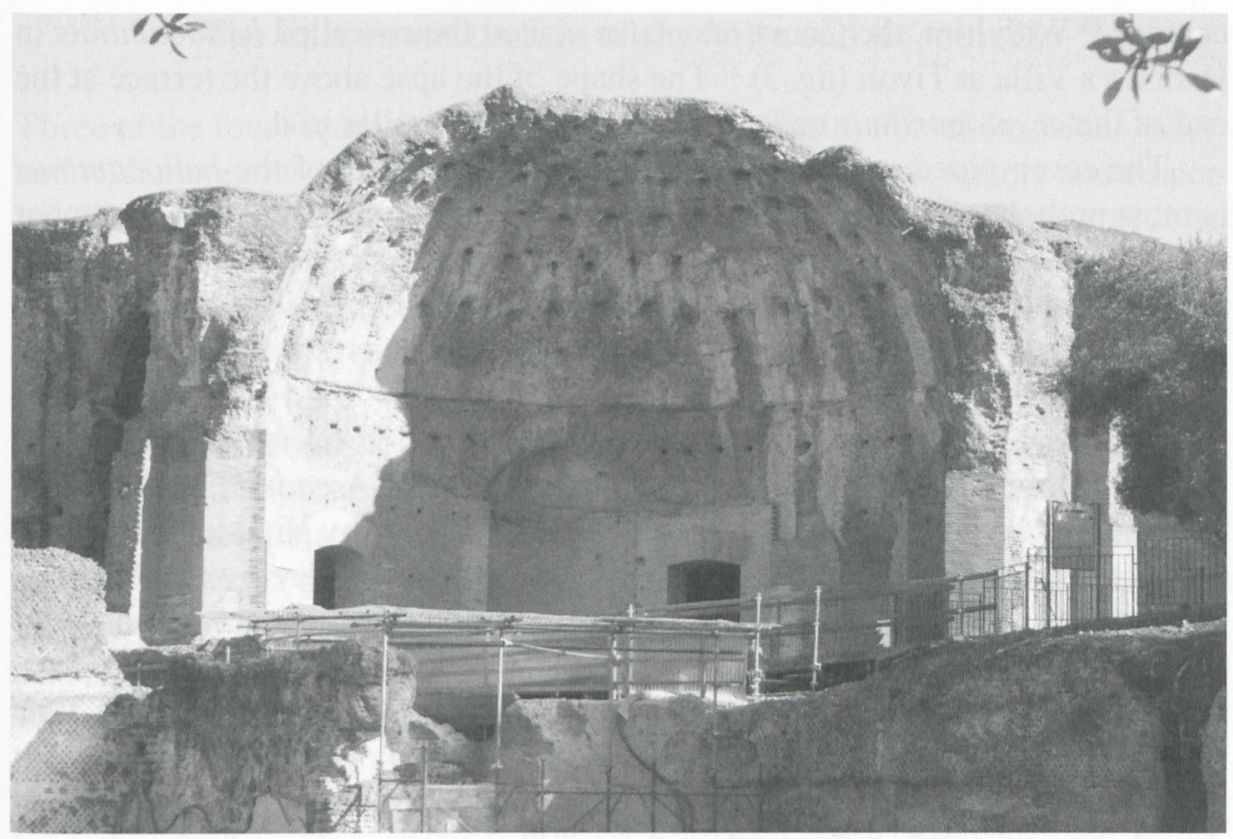

Fig. 3 The so-called Heliocaminus in Hadrian's Villa at Tivoli

eagles supporting garlands. The latter motif is to be found in one of Piranesi's etchings as well as in the temple of Diana at Nîmes. ${ }^{24}$ Potocki had visited Nîmes during his studies in Turin and he mentioned the famous temple in his Notes and in a letter to his older brother, Ignacy.

The Notes contain the following commentary concerning the sun-parlour:

After a great deal of research and misunderstandings about the way the heliocaminus might have been constructed - a few scholars wrongly made it a sitting room, others an entirely open and raised place - M. Orlandi, a learned antiquarian, pointed out to me, among the scattered ruins found between Tivoli and Rome, a sort of semi-circular vaulted niche designed to prevent the heat of the sun and protect against cold winds. He assured me that, after intensive research, he had become convinced that this was the true heliocaminus of the ancients. His idea agreed so well with what Pliny says that I did not hesitate to adopt it. ${ }^{25}$

Only recently the »learned antiquarian« was identified as Orazio Orlandi, the author of several books on Antiquity published in the latter half of the eighteenth

24 See Clérisseau (1995), Fig. 40 and in one of the etchings of Piranesi, see Scott (1975), 224, Fig. 270; this a design for a fireplace executed for the Dutch banker, John Hope.

25 Miziołek (2006), 35. 
century. ${ }^{26}$ With him, the Count may have visited the so-called heliocaminus in Hadrian's Villa at Tivoli (fig. 3). ${ }^{27}$ The shape of the apse above the terrace at the end of the cryptoporticus under discussion is very similar to it.

The seven-piped syrinx in the wreath above the apse of the heliocaminus is most probably linked to the fact that since 1775 Potocki had been a member of the Society of Arcadians, the famous Roman association of men of letters. ${ }^{28}$ Eleven years later Goethe also became a member and his Italian Journey contains a beautiful description of his admission to the Society which ends with the following sentence:

»The seal [on the diploma] shows a wreath, half laurel, half pines, in the centre of which is a syrinx. Underneath, the words: Gli Arcadi. $\aleph^{29}$ Potocki's diploma, adorned with a syrinx within a wreath and signed by Nivildo Amarinzio, the custode, has fortunately been preserved at the National Archives in Warsaw. While conceiving and creating the reconstruction of the Laurentina, the Count obviously identified himself - to some degree - with the owner of the legendary villa.

Potocki, like Castell, was convinced that Pliny had planned for not one, but two pavilions at the ends of the cryptoporticus; these can be seen on the plan of the whole estate and on three other plates. ${ }^{30}$ Two of them show the façades and the ground plan of both pavilions, while the third depicts the interior decoration. It is possible to identify the antique prototype for most of the motifs; two major sources are to be found in the towns of Vesuvius and the Domus Aurea. ${ }^{31}$ The obvious adoption of the decoration from the latter, namely from the camera a volta nera, is visible at first glance in one of the pavilion's rooms facing the sea. In both cases the wall is divided into large compartments in the middle of which small still lives or scenes with figures on either black or white background are assembled. This is an excellent example of the Fourth Pompeian style.

26 Orlandi (1773); Orlandi (1772). The former work contains the etchings produced after Franciszek Smuglewicz's drawings.

27 For Tivoli's so-called heliocaminus see Paribeni (1926), 75-79; Verduchi (1975), 55-95; Cicerchia (1985), 45-60.

28 See Miziołek (2007), 40-42. For Potocki as a member of the Society of Arcadians, see Grochulska (1984/85), 159. For interesting observations on this Society, see Goethe (1970), 442-446.

29 Goethe (1970), 446.

30 Castell (1728), 44ff.

31 See Miziołek (2007), 138, Figs. 128-129. 


\section{The interior decoration of the Villa and its sources}

Three of the four façades of the villa are - according to Potocki's vision - adorned with numerous statues of gods, goddesses, philosophers, orators and emperors. The impression arises that Potocki wanted to adorn the Laurentina with the most famous sculptures of the glorious period of the Imperium Romanum that were on display in eighteenth-century Rome. Such an approach may have again been inspired by Pliny the Younger. We know from one of his letters to Trajan that he owned several statues of Emperors, including one of Trajan himself. ${ }^{32}$ Therefore, it is not surprising that the main façade of Potocki's Laurentina is adorned with an imperial portrait resembling that of Trajan which may have been patterned after a statue, similarly to the one at Ostia. ${ }^{33}$ Eight other statues of Emperors adorn a building depicted on a drawing in the album Intérieure de la Villa de Pline le jeune par Brenna. This building does not correspond with any part of the Laurentina ground plan. It was most probably produced in 1777 or in 1786 when Potocki, again in Rome, returned to his villa project. ${ }^{34}$ The drawing is proof of the fact that Potocki not only carefully studied the letters describing Pliny's villa, but also the aforementioned letters sent to Trajan.

Many of the sculptures adorning the façades as well as those used in the interior are more or less faithful replicas of famous ancient statues of gods and heroes such as Hercules Farnese and Hercules Victor, Apollo Belvedere, Mercury, Aesculapius, Dionysus, Diana, Hygeia and Isis. The statue of Hercules located at the sea façade is an interesting composite of two famous ancient statues: Hercules Victor and Hercules Farnese (fig. 4) ${ }^{35}$ It is immediately discernible that the long legs and the way in which the head is presented are reminiscent of the former (fig. 5), while the positioning of the arms clearly recalls the latter (fig. 6). Composites or adaptations of antique prototypes are to be observed not only in regard to statues but as well in regard to the paintings adorning some of the Laurentina rooms which will be treated at a later point.

An interesting example of Potocki's re-invention of antiquity is the decoration of the pediment of the sea façade. On the top an Emperor (Nerva or Trajan) in a quadriga is shown (see fig. 1), as if the edifice was a public building. The quadriga is mounted on a platform which has the form of a five-stepped pyramid; in this case it seems that Potocki derived his inspiration from Pliny the Elder's description of the Mausoleum at Halicarnassus. In his Natural History it

32 Pliny the Younger, Letters, X, 8

33 See Miziołek (2006), 27-28, plate 14.

34 Potocki's letter dating from March $4^{\text {th }}, 1786$ in which he refers to the Laurentina project is cited in Grand Tour (2006), 161.

35 For the Hercules Victor and the Hercules Farnese, see Haskell/Penny (1981), nos. 45-46, 227232, Figs. 117-118. 


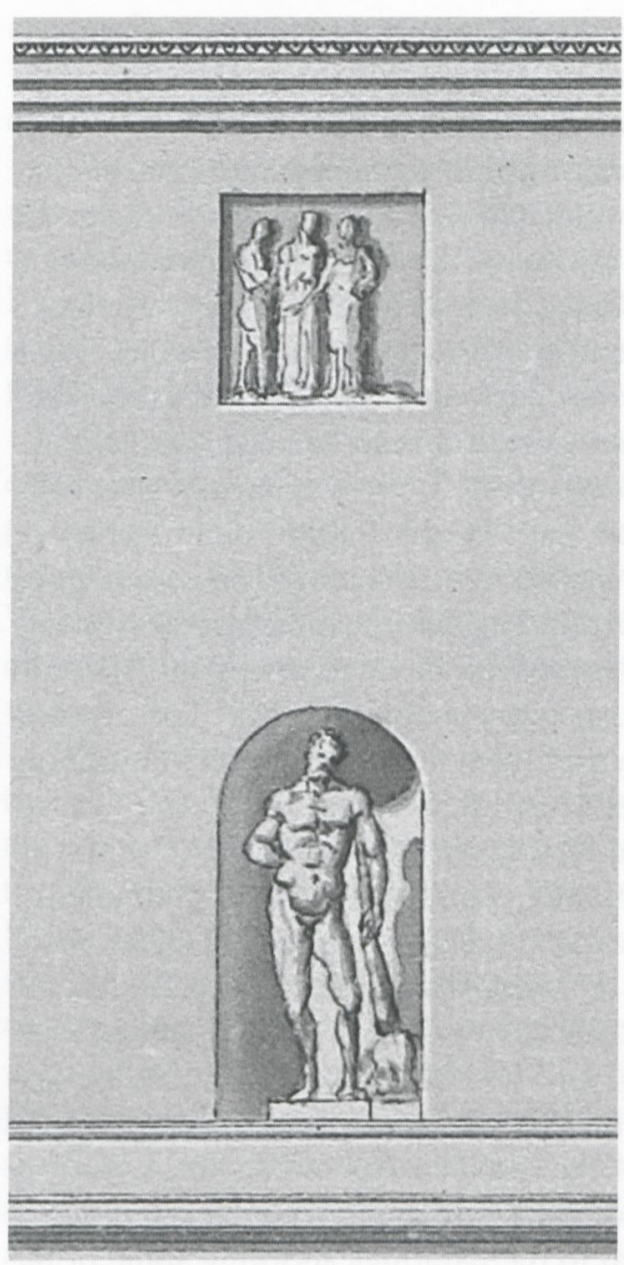

Fig. 4 Stanislaus K. Potocki, Vincenzo Brenna, Laurentina Villa, Statue of Hercules on the sea façade, coloured drawing, Warsaw, National Library reads: »Above the colonnade [of the Mausoleum] there is a pyramid as high again as the lower structure and tapering in 24 stages to the top of the peak. At the summit there is a fourhorse chariot of marble ${ }^{36}{ }^{36}$ Another source of inspiration may have been Potocki's collaborators themselves, since a similar quadriga is visible above a triumphal arch in a drawing by Brenna and Smuglewicz depicting the Forum of Trajan. ${ }^{37}$

Most interiors of the villa, such as the baths and triclinia, or dining rooms, are also adorned with statues. Some of the drawings executed by artists less gifted than Manocchi show rather poor drawings of famous originals. One example in question is the statue of Isis in the room adorned with the Three Graces, hence called the Room of the Three Graces. The statue was apparently patterned after the Isis found in Hadrian's Villa at Tivoli which has been on display at the Musei Capitolini since the eighteenth century. The draughtsman most probably Brenna - who, unfortunately, did not capture the beauty of the original, may have known it from an engraving by Bottari published in $1755^{38}$

In the main triclinium or dining room, which is one of the finest rooms in the villa, there are statues of Hygeia, Dionysus and Diana (fig. 7). Both statues of Dionysus are faithful copies of the statues which can still be seen in one of the rooms of the Borghese Gallery in Rome, whereas Diana seems to be patterned

36 Pliny the Elder, Natural History, XXXVI, 4, 32.

37 See Christie's, December $6^{\text {th }}, 1988$, lot 107 . The drawing is attributed to Brenna but the figures in it are clearly by Smuglewicz.

38 Bottari (1755), plate 73. 


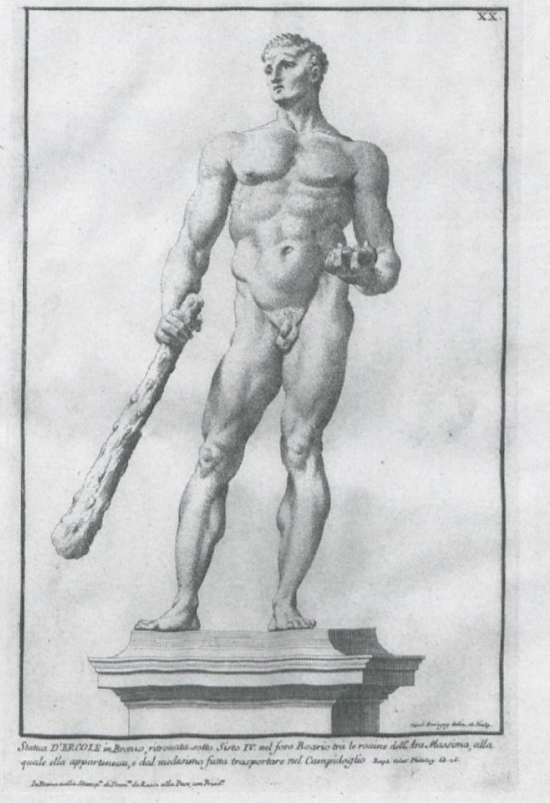

Fig. 5 Domenico de Rossi, Hercules victor, etching in: Raccolte di statue antiche e moderne (1704)

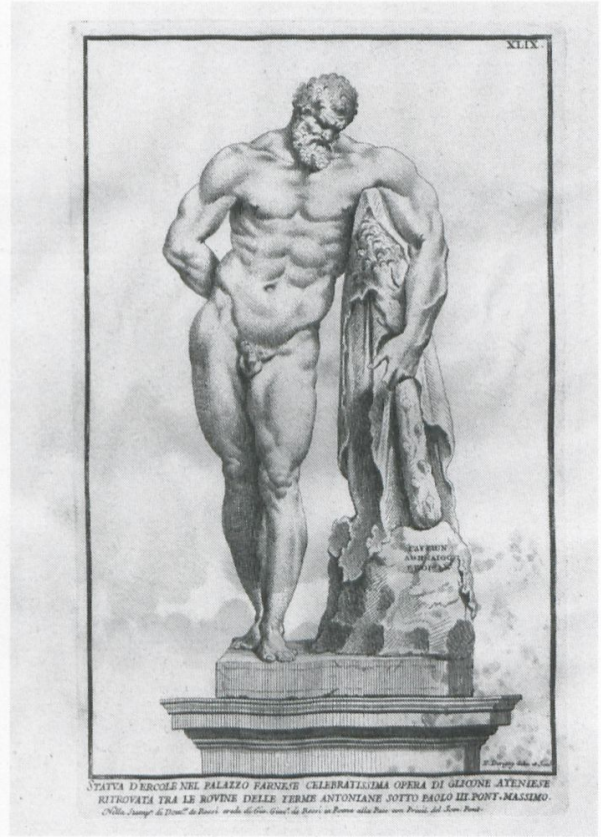

Fig. 6 Domenico de Rossi, Hercules Farnese, etching in: Raccolte di statue antiche e moderne (1704)

after the statue from Gabii, now in the Louvre. ${ }^{39}$ In the case of Hygeia it is quite possible that it was patterned after a statue of the goddess drawn by Francesco Bartoli. ${ }^{40}$ Unfortunately, the present whereabouts of the statue are unknown to the author. However, the artist who executed the drawing, or Potocki himself, may have used Françoise Perrier's famous book Segmenta nobilium signorum et statuarum (figs. $8,9,10,11){ }^{41}$ Beautiful, although not quite faithful etchings of all four of the above statues can be found in this book, which is preserved to date in Potocki's library in the National Library, Warsaw. ${ }^{42}$

One of the most impressive of all the interiors in Potocki's reconstruction of the Laurentina are the baths, which include the frigidarium and unctorium, that

39 For the statues of Dionysus, see Moreno/Stefani (2008), 132, 134, both are Roman $2^{\text {nd }}$ century A.D. copies of Greek originals. For Diana (Artemis) from Gabii see Marvin (2008), 85.

40 The drawing belonging to the Museum of Fine Arts, San Francisco has not yet been published.

41 Perrier (1638), passim.

42 Interesting observations on the limited faithfulness of the engravings in 17th and 18th century books as well as on inventions, variations and capricci of copy makers see Sénéchal 1986, 15180 , esp. $166-177$. 


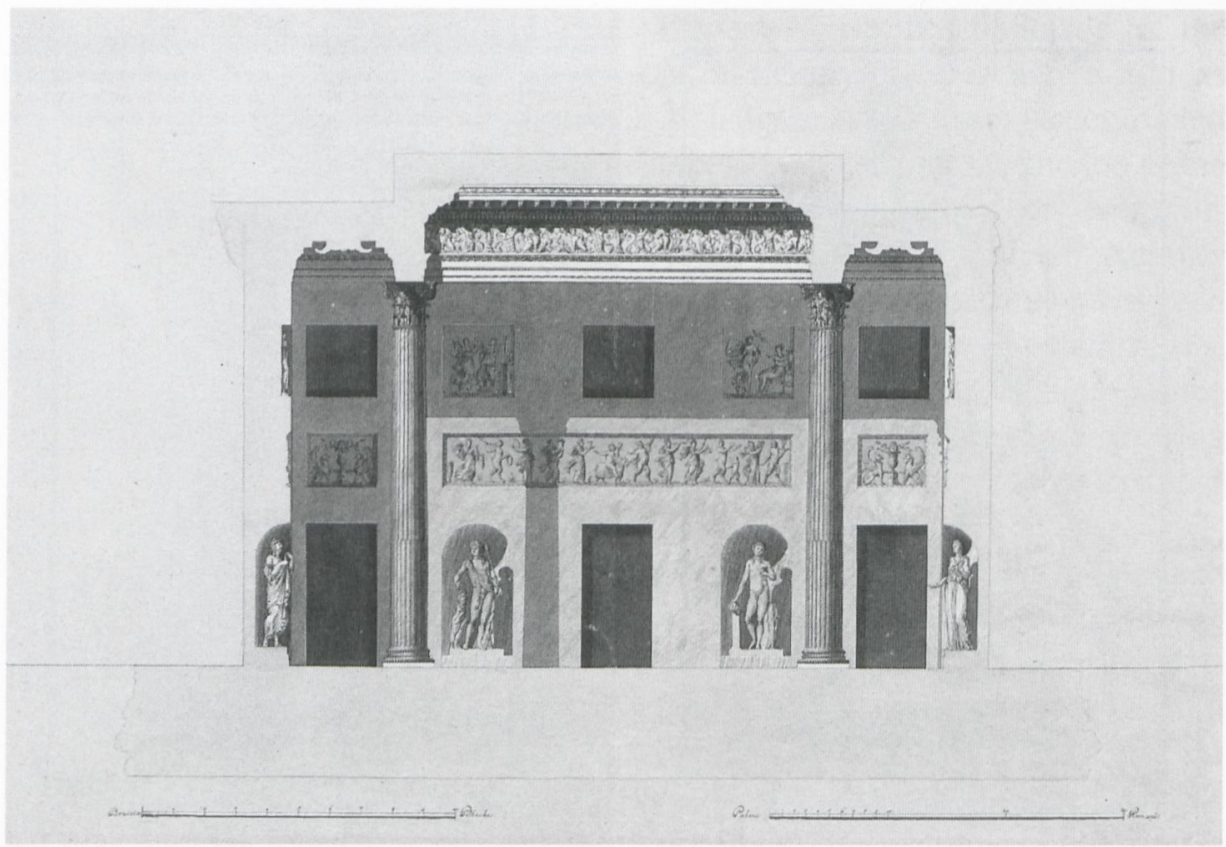

Fig. 7 Stanislaus K. Potocki, Vincenzo Brenna, Franciszek Smuglewicz (?), Laurentina Villa, Triclinium, coloured drawing, Warsaw, National Library

is »the place designated for rubbing oneself down before entering the bath and for applying cologne upon leaving it« (fig. 12). ${ }^{43}$ The Notes read:

[Baths] became the repositories of masterpieces of art, places of place for the Roman people. [...] Well-off individuals had private baths in their homes, such as those Pliny speaks of, whose luxury and elegance were no less surprising. According to the ancients, the brilliance of gold, paint, sculpture, and the rarest stones vied for attention. ${ }^{44}$

The unctorium drawn by Manocchi is a masterpiece. It consists of a beautiful Pantheon-like rotunda, adorned with two tripod perfume burners and two niches on either side, and within this rotunda there is a shrine-like space with a statue group on a pedestal embodying a couple gazing tenderly at each other while embracing. Could they be Cupid and Psyche representing the Count and his beloved wife Alexandra? The pedestal is adorned with a >selective< citation

43 I attributed this drawing to Manocchi, having examined many of his drawings housed in the Sir John Soane's Museum. The high artistic quality of the drawing showing the unctorium, comparable with the aforementioned depiction of Hebe and Hercules, among others, was also noticed by Ruffinière du Prey (1994), 152; he presumed that Smuglewicz may have executed it.

Potocki in: Miziołek (2006), 34. 


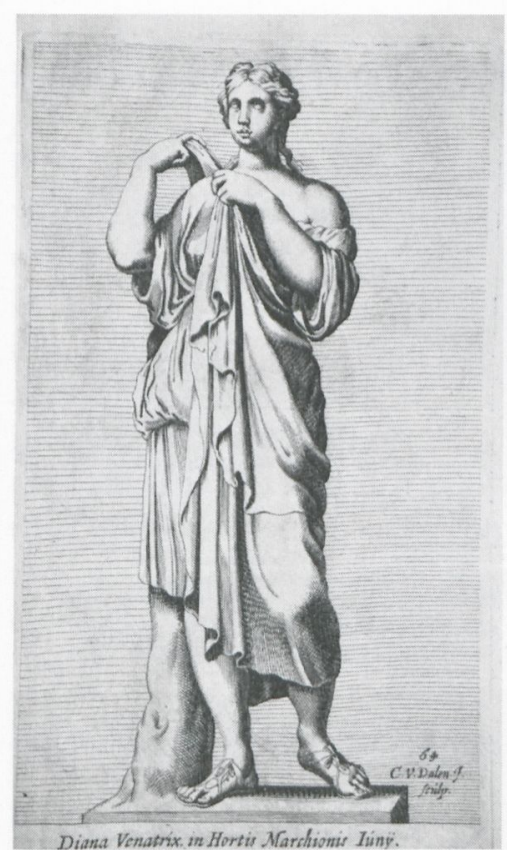

Fig. 8 Artemis (Diana) from Gabii, engraving in: Perrier (1638)

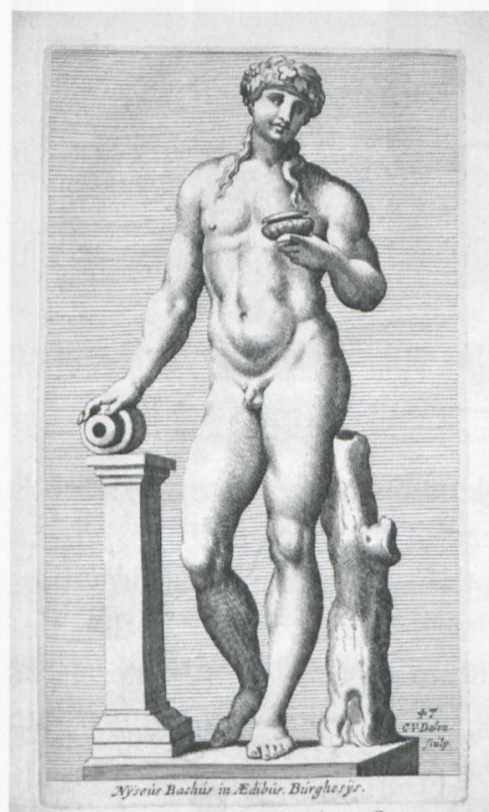

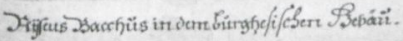

Fig. 10 Dionysus with a cup, engraving in: Perrier (1638)

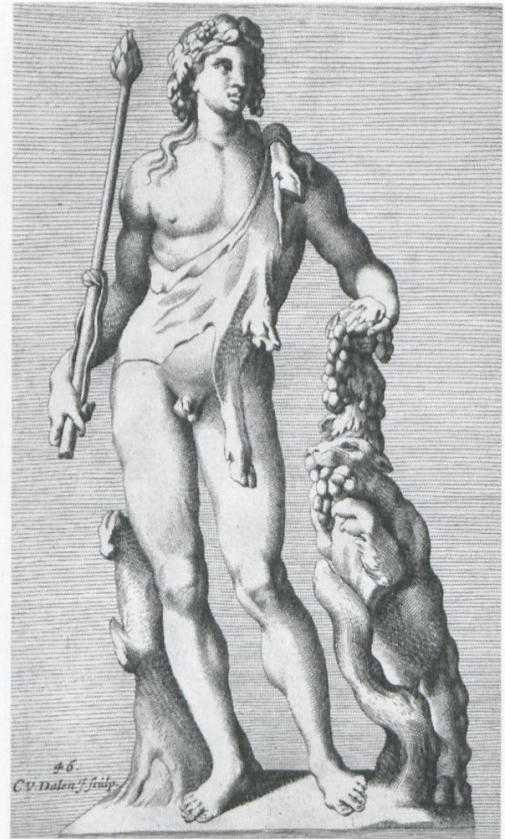

Fig. 9 Dionysus with a panther, engraving in: Perrier (1638)

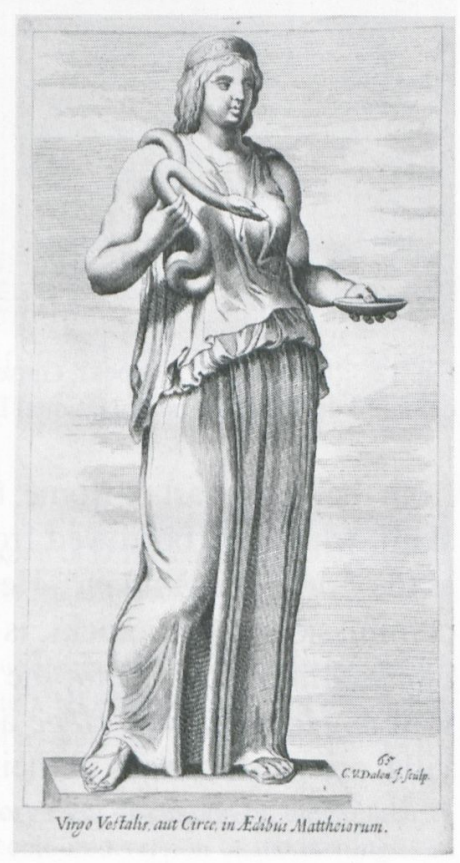

Fig. 11 Hygeia (Salus), engraving in: Perrier (1638) 


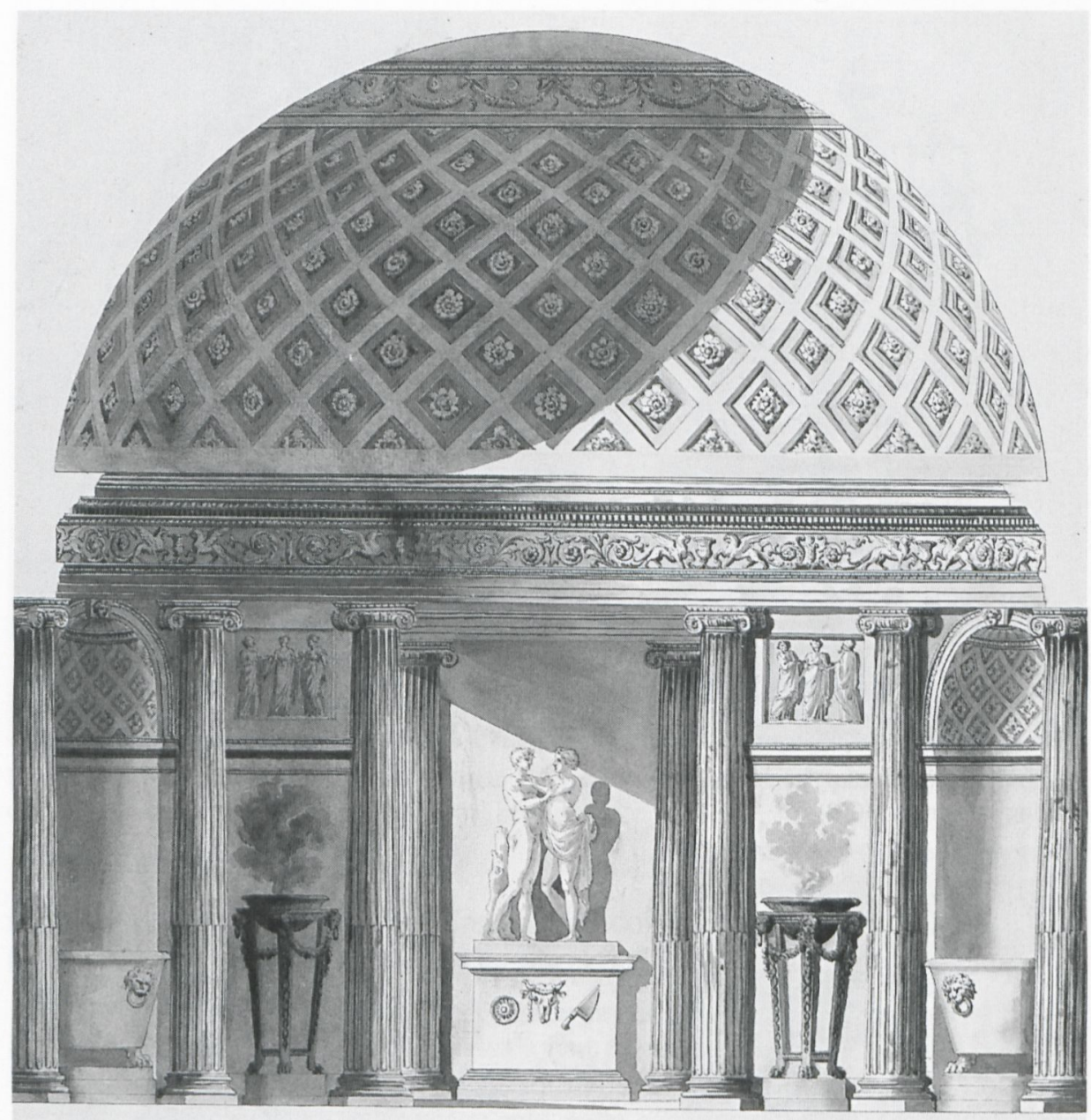

Fig. 12 Stanislaus K. Potocki, Giuseppe Manocchi, Laurentina Villa: frigidarium and unctorium, coloured drawing, Warsaw, National Library

from the very heart of Rome; that is with the implements of sacrifice and a bull's skull, which are borrowed from the famous frieze of the Temple of Vespasian at the Forum Romanum. ${ }^{45}$ Here Manocchi, as in the case of the other drawings commissioned by Potocki, is not simply a maker of copies, but an artists demonstrating his inventio; the aforementioned statues of Cupid and Psyche, as well as Hercules and Hebe adorning the ceiling in the main triclinium of the villa, are masterpieces in their own right. ${ }^{46}$

45 For this famous frieze, see Roma antiqua (1985), 80.

46 For the Hercules and Hebe drawing, see Miziołek (2007), 100, Fig. 76. 
A very interesting adaptation from one of the archaeological books published in the 1770 s is to be found in a drawing depicting one the niches of the frigidarium. It clearly recalls the famous homage to Winckelmann, which Pierre F. H. d'Hancarville produced for the third volume of his book about ancient vases in the William Hamilton collection. ${ }^{47}$ In both cases we see a sarcophagus or labrum adorned with lions' heads and niches with lozenge-shaped coffers. In turn the motif of the Griffins adorning the friezes in both of the recently discussed drawings appears to be borrowed from the frieze of the Temple of Antoninus and Faustina at the Forum Romanum. ${ }^{48}$ Moreover, the niches shown in figure 12 with their lozenge-shaped coffers are patterned after the apses of the Hadrianic Temple of Venus and Roma. Therefore, as in the other rooms of the Laurentina, in the baths complex there is an eclectic mix of ornamental details which are used to produce new and quite original forms acceptable to late eighteenth-century viewers.

The frescoes on the walls, ceilings and in the niches of several of the Laurentina's rooms are more or less faithful copies or adaptations of ancient art. They derive not only from the murals in the Domus Aurea but also from the ceiling stuccos in Hadrian's villa at Tivoli, as well as from the murals that were uncovered around mid-eighteenth century in the town of Vesuvius. An interesting combination of themes and decorative motives taken from a variety of sources - including antique gems - is to be found in the villa's cenatio (fig. 13). ${ }^{49}$ The scene depicting the Centaur Chiron and Achilles was adapted from a painting found in the so-called basilica at Herculaneum. Even if the poses of both protagonists differ somewhat from the original, there is no doubt that the scene was patterned on one of the etchings in the first volume of Le Antichità di Ercolano esposte or on a coloured version of it to be found in an unpublished plate in the Print Collection of the University of Warsaw Library. ${ }^{50}$ In turn, the figure shown on the left of the Centaur Chiron and Achilles undoubtedly recalls the ecstatic bacchic satyr with a thyrsus in hand on an ancient cameo,

47 See Jenkins/Sloan (1996), 148, no. 31. See also the new edition of D'Hancarville (2004), 162.

48 This quotation was noticed by Ruffinière du Prey (1994), 161. In Manocchi's drawing the temple with its frieze appears several times.

49 Miziołek (2007), 125-136; Ruffinière du Prey (1994), 165 wrote about the three drawings which in M. Baliszewski's, M. Tarkowski's and my opinion create a set of drawings being an attempt for Potocki's reconstruction of the cenatio: "Ironically, not a single one fits with any part of the Laurentine scheme«.

50 Antichità di Ercolano esposte (1757), vol. 1, plate XLIII; for recent discussion on the popularity of this painting see Najbjerg (2007), 59-72. The Warsaw coloured version of the etching is in $\mathrm{Zb}$. Król. vol. 513. Another coloured version of the same etching is in the Louvre, see Pinot de Villechénon/Napoleone (2000), 98-99, Plate 31. 


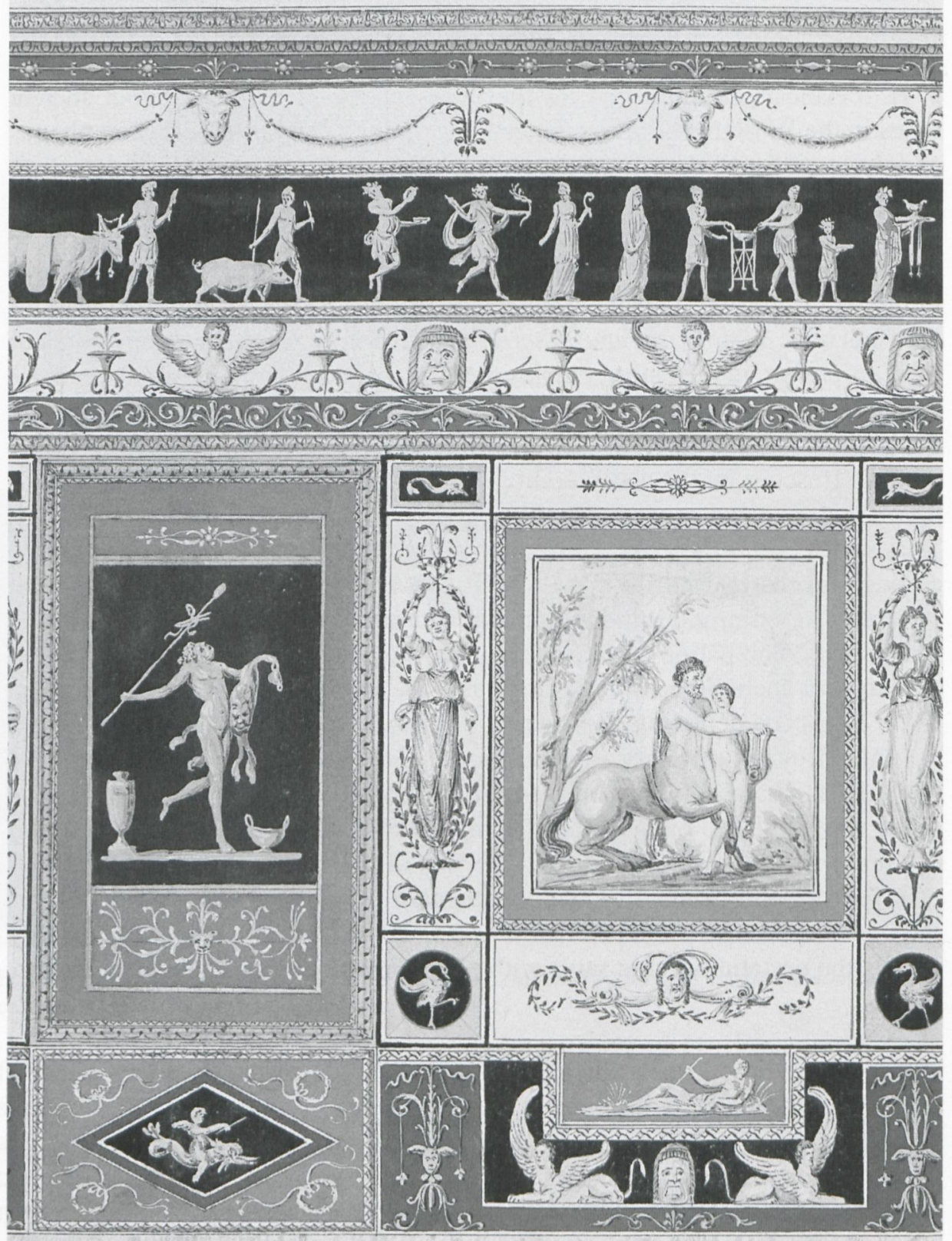

Fig. 13 Stanislaus K. Potocki, Vincenzo Brenna, Decoration of the cenatio with the Dancing bacchic Satyr, Warsaw, National Library 
which was also known at that time from etchings, ${ }^{51}$ whereas the motif of two boys travelling on a goat, depicted on the second drawing from the set under discussion, derives again from one of the murals in the Domus Aurea.$^{52}$ Thus, in the Notes, Potocki could indeed say: »Herculaneum, Pompeii, the Bay of Naples [...] the Baths of Titus [...] were of no small aid in the choice of ancient paintings, ornaments, and mosaics [for the Laurentina project].« Thus, it can be concluded that the copies and adaptations of antique masterpieces used by Potocki for the reconstruction of Pliny's Laurentina, in some way became originals.

\section{Instead of a conclusion: Offshoots of the Laurentina project}

Among the drawings which up to this day have usually been linked to the Laurentina project, two are of particular interest to us. One of them, preserved in the album entitled Villa de Pline le jeune dite Laurentina, is by Manocchi, the second entered into the album of plates depicting the interiors of the villa by Brenna (Intérieure de la Villa de Pline le jeune par Brenna). In my opinion they do not belong to the Laurentina project but are an offshoot of it. Brenna's drawing presents a villa or a pavilion with a façade adorned with several statues of emperors, while the interior features a very interesting decoration in the Pompeian style and two statues. ${ }^{53}$ The latter statue, which stands in the central space, clearly recalls the Apollo Belvedere and Aesculapius at once in typical pose with a serpent winding round his staff. In a very similar manner, Robert Adam used ancient statues to decorate the interiors of Syon House, which he had re-modeled slightly earlier. ${ }^{54}$

Manocchi's beautiful drawing shows a magnificent sculpture gallery with, among others, masterpieces such as the Aphrodite of Cnidos and Satyr by Praxiteles (fig. 14). The drawing appears to have been commissioned for the Projects des Bâtiments (d)'un Musée des Beaux-Arts de Composition de Comte Stanislaus Potocki, which is also being preserved in the National Library, Warsaw. ${ }^{55}$ Since Manocchi died in 1782 it must have been produced in 1780 or earlier. This time the Italian artist put aside his inventio; he produced what he was asked for - a gallery of plaster casts which was such a fashionable

51 See Miziołek (2007), 125-126. This motif, very popular in Neoclassical art, may have been borrowed also from an antique marble vase reproduced in Piranesi's Vasi, candelabra, cippi (1778), see Ficacci (2000), no. 771; the antique gem is reproduced in Mariette (1732), no. 40.

52 See Miziołek (2006), plate 31.

53 See Miziołek (2007), 149, plates 138-139.

54 See Piranesi, Ficacci (2000), no. 609.

55 Miziołek (2007), 149, fig. 133. 


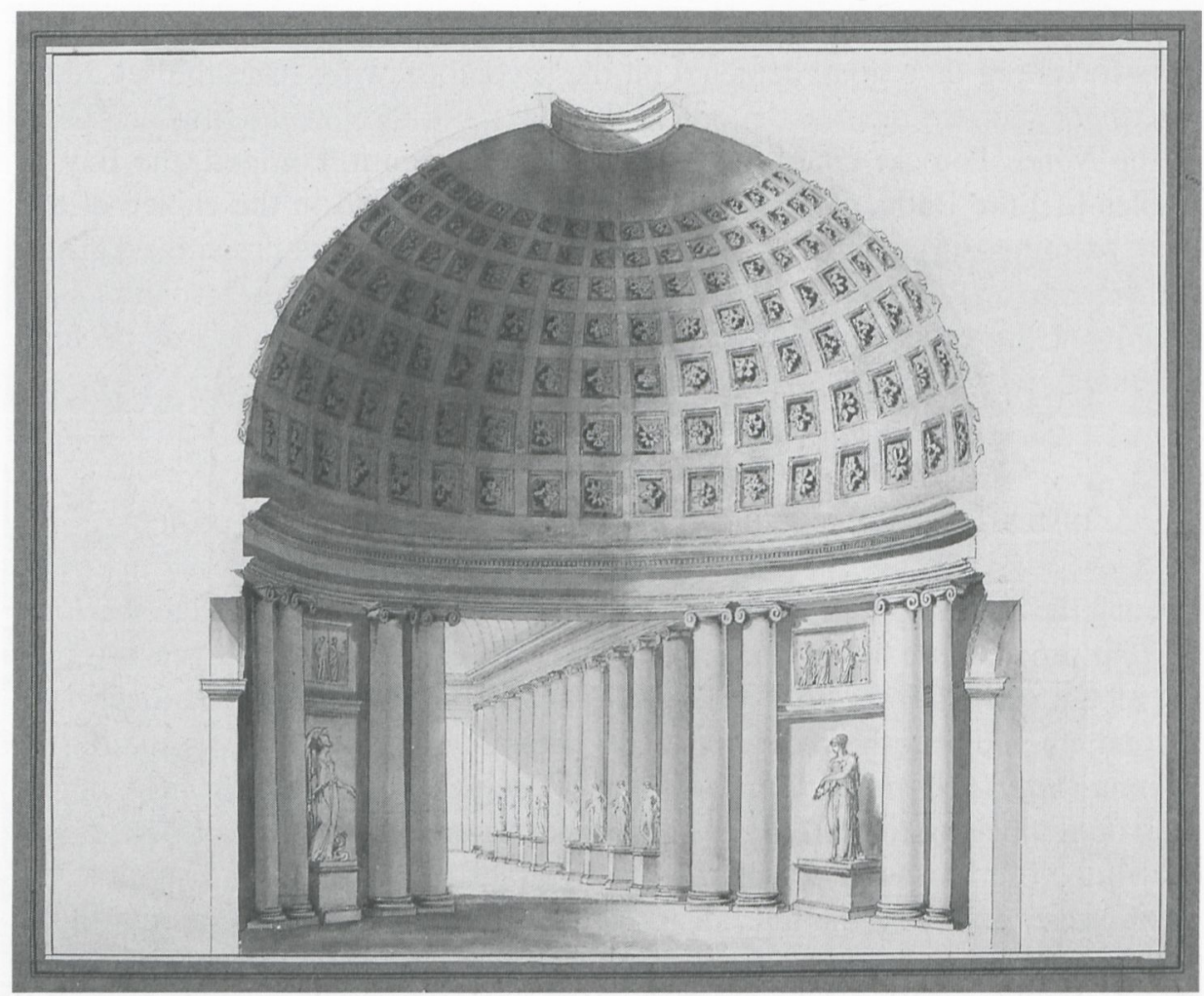

Fig. 14 Stanislaus K. Potocki, Giuseppe Manocchi, Project of the Museum of Fine Arts, coloured drawing, Warsaw, National Library

thing to have in the latter half of the eighteenth century. Count Potocki kept in mind his ambitious project born in Rome which was to create, in Warsaw, a large collection of plaster casts of antique statues. Between 1808 and 1820 when he served as the Minister of Education he created such a gallery at the University of Warsaw, which was founded at that time. In the late $1820 \mathrm{~s}$ the collection included more than 750 plaster casts made in Rome, Paris and Berlin (fig. 15). For more than 100 years students of the fine arts in Warsaw benefited greatly from the collection of casts. ${ }^{56}$ This time the Polish Winckelmann's idea, conceived in his youth when working on the Laurentina project, was converted into reality.

56 On the University gallery of plaster casts, see Miziołek (2005), 111-117; Kowalski (2008), passim. 


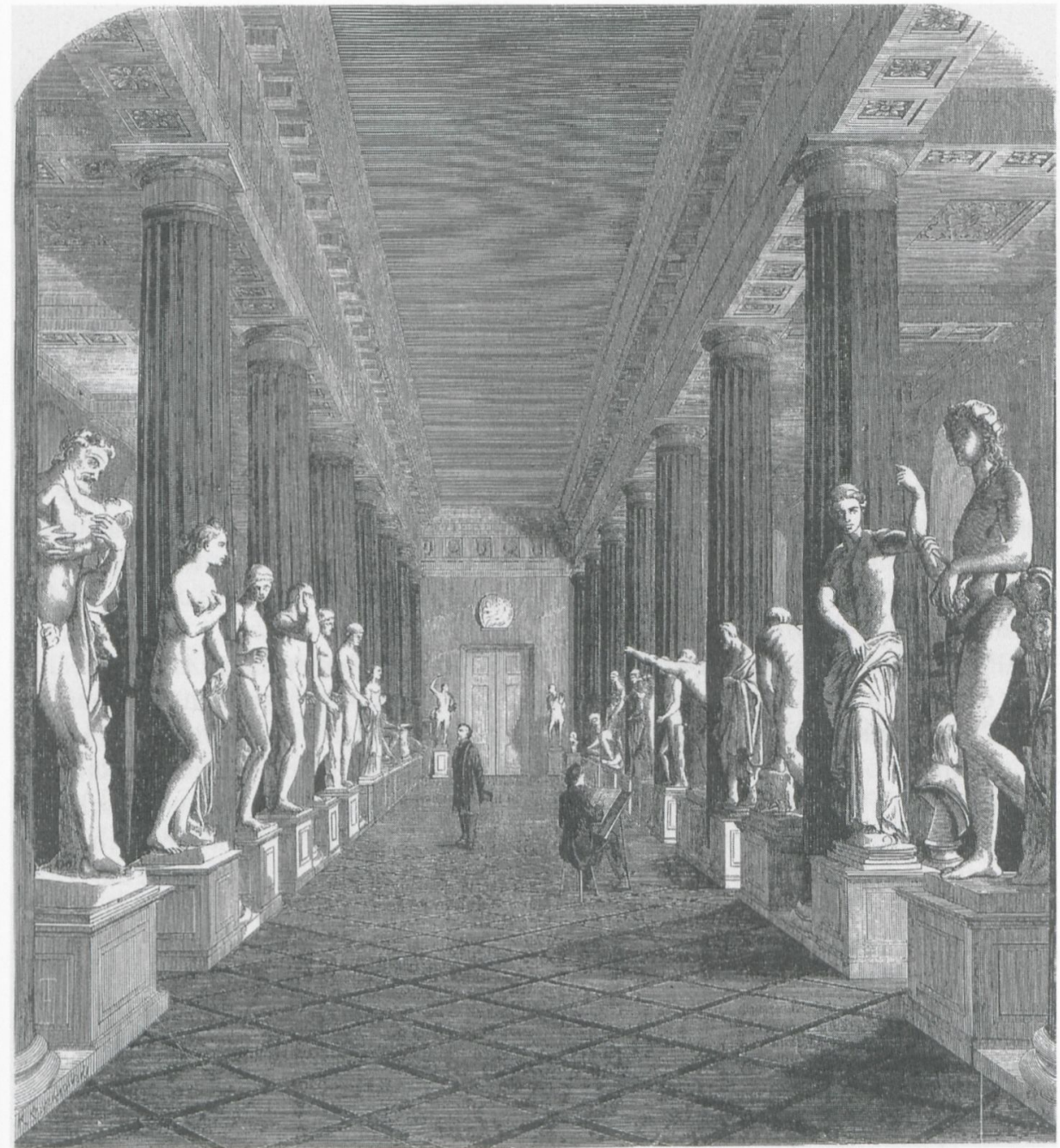

Fig. 15 F. Tegazzo, K. Krzyżanowski, Gallery of Plaster Casts at the University of Warsaw, engraving

It is to be assumed that if Potocki had published his reconstruction of Pliny the Younger's villa maritima together with his Notes et Idées sur la Villa de Pline before the end of the eighteenth century, its impact on Neoclassical art may have been greater than the publications of Mirri and Nicolas Ponce. ${ }^{57}$

57 For Ponce's publication of the murals in the Domus Aurea in 1786 ( $2^{\text {nd }}$ edn. 1805), see Perrin (1982), 883-891. 


\section{Zusammenfassung}

Antikenrezeption in den 1770er Jahren. Die Dekoration der Villa Maritima Plinius des Jüngeren in den Vorstellungen Graf Stanislaw K. Potockis.

Gegenstand des Aufsatzes ist ein weitgehend unbekanntes Meisterwerk - eine Idealrekonstruktion der Villa Plinius des Jüngeren in Laurentum, ursprünglich errichtet im ersten Jahrhundert v. C. nahe Rom an der Küste des Mittelmeeres. Die Rekonstruktion nach Entwürfen Graf Stanislaw K. Potockis wurde 1777-78 in Rom in 36 großen Farbzeichungen auf Papier $(57,7$ x 89,5 cm) durch italienische und polnische Künstler ausgeführt. Graf Potocki, als Dilettant, Architekt und Archäologe stattete die Rekonstruktion verschwenderisch aus, inspiriert durch die Ausgrabungsergebnisse der Domus Aurea, der »Städte des Vesuvs« und der Hadriansvilla bei Tivoli. Die Zeichnungen, detailliert bis zur Darstellung zahlreicher Kaiserstatuen, der Dekorationen der Haupträume im pompejanischen Stil und einer Kryptoportikus, bilden den Grundriss der Villa zusammen mit allen vier Aufrissen ab und schufen so die einmalige Möglichkeit, Außenbau und Innenräume der Villa auch virtuell zu rekonstruieren, was mit Hilfe des 3D Studios Max 8 gelang.

Plinius Beschreibung der Laurentina in seinem berühmten Brief An Gallus übte über die letzten fünf Jahrhunderte immensen Einfluss auf all jene Menschen aus, die selbst Villenbauten planten und verwirklichten - von Lorenzo de'Medici, Andrea Palladio, Vincenzo Scamozzi über Thomas Jefferson bis Leo Krier. Zahlreiche Rekonstruktionen auf Papier haben die Laurentina wiederzubeleben versucht, und doch stellen die 36 Zeichnungen des 18. Jahrhunderts aus der Nationalbibliothek Warschau den umfangreichsten, jemals unternommenen Rekonstruktionsversuch der Villa dar. Doch stützte Potocki seine Arbeit nicht allein auf die Briefe des Plinius, sondern auch auf die Überreste der Laurentina, die 1714 in der Nähe von Ostia gefunden worden waren. Durch seine Vorgehensweise wurde Graf Potocki zum Wegweiser für die Etablierung der wissenschaftlichen Disziplinen Archäologie und Kunstgeschichte in Polen.

Für die skulpturale Dekoration der Fassaden und Innenräume griff Potocki auf im 18. Jahrhundert bekannte Antiken zurück, die zumeist in Stichwerken veröffentlicht worden waren. Er ließ diese in den Zeichnungen nicht nur kopieren, sondern schuf mitunter auch neue Kombinationen und Adaptionen, wie z.B. einen Hercules, der sowohl Elemente des Hercules Victor als auch des Hercules Farnese vereint. Durch die Praxis des Kopierens kreierte Potocki neue Originale. 


\section{Bibliography}

(Le) Antichità di Ercolano esposte, vols.1-8, Napoli 1757-1792.

Bentkowska, Anna, »Potocki, Stanisław K.«, in: Dictionary of Art, vol. 25, ed. by Jane Turner, London 1996.

Bottari, Giovanni Gaetano, Musei Capitolini tomus tertius continens deorum simulacra aliaque signa cum animadversionibus, Roma 1755.

Carletti, Giuseppe, Le antiche camere delle terme di Tito e le loro pitture, Roma 1776.

Castell, Robert: The Villas of the Ancients, London 1728.

Cicerchia, Pietro, »Sul carattere distributivo delle >terme con heliocaminus< di Villa Adriana«, in: Xenia, vol. 9 (1985), 45-60.

Clérisseau, Charles-Louis, Dessins du musée de l'Ermitage Saint-Pétersbourg, Saint-Pétersbourg 1995.

Culot, Maurice/Pinon, Pierre, La Laurentine et l'invention de la villa romaine, Exhibition Catalogue, Paris 1982.

Evers, Bernd, Das Schöne am Nützlichen. Ornament und Architektur, Katalog zur Ausstellung, Berlin 2007.

Ficacci, Luigi, Giovanni Battista Piranesi, Köln/London et. al. 2000.

Fascination de l'Antique: 1700-1770 Rome découverte, Rome inventée, éd. François de Polignac (Exh. Catalogue: Lyon, Musée de la civilisation gallo-romaine, 20 XII 1998 14 III 1999), Paris 1998.

Förtsch, Reinhard, Archäologischer Kommentar zu den Villenbriefen des Jüngeren Plinius, Mainz am Rhein 1993.

Grand Tour. The Birth of a Collection of Stanisław Kostka Potocki, Warsaw 2006.

Goethe, Johann Wolfgang, Italian Journey (1786-1788), trans. by Wystan Hugh Auden and Elizabeth Mayer, London 1970.

Grochulska, Barbara, »Potocki Stanisław Kostka«, in: Polski Słownik Biograficzny, vol. XXVIII, (1984-1985), 158-170.

D'Hancarville, Pierre-François Hugues, The Collection of Antiquities from the Cabinet of Sir William Hamilton, ed. by Sebastian Schültze, Köln/London 2004.

Haskell, Francis/Penny, Nicholas, Taste and the Antique, New Haven/London 1981.

Archeologia, letteratura, collezionismo, Atti del Convegno dedicato a Jan e Stanisław Kostka Potocki, ed. Elżbieta Jastrzębowska/ Monika Niewójt, Roma 2008.

Jenkins, Ian/Sloan, Kim, Vases and Volcanoes: Sir William Hamilton and his Collection, London 1996.

Kowalski, Hubert, Antyczne tradycje w dekoracji rzeźbiarskiej gmachów Uniwersytetu Warszawskiego przy Krakowskim Przedmieściu, Warszawa 2008.

Lanciani, Rodolfo, »Le antichità del territorio laurentino nella tenuta reale di Castelporziano«, in: Monumenti antichi pubblicati dall'Accademia dei Lincei, XIII (1903), 133-198.

Mariette, Pierre-Jean, Receuil des pierres gravée du Cabinet du Roy, Paris 1732.

Marvin, Miranda, The Language of the Muses. The Dialogue between Roman and Greek Sculpture, Los Angeles 2006.

Miziołek, Jerzy, Uniwersytet Warszawski. Dzieje i tradycja, Warszawa 2005.

Miziołek, Jerzy, »In the Pure Taste of Trajan's Century<. Preliminary Observations on Pliny the Younger's Laurentina as Imagined by Count Stanislaus Kostka Potocki«, in: Swiatowit, VI (2006), 25-42.

Miziołek, Jerzy, Villa Laurentina. Arcydzieło epoki stanisławowskiej, Warsaw 2007. 
Moreno, Paolo/Stefani, Chiara, The Borghese Gallery, Milano 2008.

Najbjerg, Tina, »From Art to Archaeology: Recontextualizing the Images from the Porticus of Herculaneum «, in: Antiquity Recovered. The Legacy of Pompeii and Herculaneum, ed. Victoria C. Gardner Coates and Jon L. Seydl, Los Angeles 2007, 59-72.

Orlandi, Orazio, Osservazioni di varia erudizione sopra un sacro cameo rappresentante il serpente di bronzo, Roma 1773.

Orlandi, Orazio, Ragionamento di Orazio Orlandi romano sopra una ara antica posseduta da Monsignore Antonio Casali governatore di Roma, Roma 1772.

Paribeni, Roberto, »Contributi archeologici al lessico latino «, in: Rendiconti Atti della Pontificia Accademia Romana di Archeologia, serie III, vol. IV, 1925-26, 75-79.

Perrier, François, Segmenta nobilium signorum et statuarum que temporis dentem invidium evase, Rome/Paris 1638.

Perrin, Yves, »Nicolas Ponce et la >Domus Aurea de Néron: une documentation inédite«, in: Mélanges de l'École Française à Rome, 94, fasc. 2, (1982), 883-891.

Pinot de Villechénon, Marie-Noelle/Napoleone, Caterina, Marie-Noëlle, Ercolano e Pompei. Gli affreschi nelle illustrazioni neoclassiche dell'album delle »Peintures d'Herculanum « conservato al Louvre, Milano 2000.

Pinot de Villechénon, Marie-Noelle, Domus Aurea: La decorazione pittorica del palazzo neroniano nell'album delle »Terme di Tito« conservato al Louvre, Milano 2002.

Pliny the Elder, Natural History, Books 33-35, with an English trans. by H. Rackham, Cambridge, Mass./London 2001.

Pliny the Elder, Natural History, Books 36-37, with an English trans. by D. E. Eichholz, Cambridge, Mass./London 2003.

Pliny the Younger, Complete Letters, English trans. by Patrick G. Walsh, Oxford 2006.

Potocki, Stanislaus Kostka, Lettre d'un étranger sur le Salon de 1787, Paris 1787.

Potts, Alex, Flesh and the Ideal: Winckelmann and the Origins of Art History, New Haven/ London 1994.

Raccolta di statue antiche e moderne data in luce sotto $i$ gloriosi auspocj della santita di n.s. Papa Clemente XI, Roma 1704.

Ramieri, Anna Maria, »La villa di Plinio a Castel Fusano«, in: Archeologia Laziale, XII, 2 (1995), 407-416.

Roma antiqua. Envois des architectes français (1788-1924), Forum, Colisèe, Palatin, Rome 1985.

Ruffière du Prey, Pierre de la, The Villas of Pliny from Antiquity to Posterity, Chicago/ London 1994.

Ryszkiewicz, Andrzej, »Portrait equestre de Stanislaus Kostka Potocki par Jacques-Louis David«, in: Bulletin du Musée National de Varsovie, vol. IV (1973), 77-95.

Salmon, Frank, »Charles Cameron and Nero's Domus Aurea: suna piccola esplorazione««, in: Architectural History, vol. 36 (1993), 69-93.

Scott, Jonathan, Piranesi, London/New York 1975.

Sénéchal, Philippe, »Originale e copia. Lo studio comparatodelle statue antichenel pensiero degli antiquari fino al 1770«, in: Memoria dell'antico nell'arte italiana. Vol. III: Dalla tradizione all'archeologia, ed. Salvatore Settis, Torino 1986, 151-80.

Stillman, Damie, Decorative work of Robert Adam, London 1966.

Tanzer, Helen, The Villas of Pliny the Younger, New York 1924.

Tarkowski, Maciej/Baliszewski, Mikołaj, »From the Enlightenment to the Digital Sunlight System. Realistic Visualisation of Count Potocki’s Laurentine Villa«, in: Światowit, VI (2006), 55-58. 
Tedeschi, Letizia, »Vincenzo Brenna (1741 - post 1806)«, in: Contro il barocco. Apprendistato a Roma e pratica dell'architettura civile in Italia 1780-1820, catalogo della mostra, Accademia Nazionale di San Luca, ed. Angela Cipriani/Gian Paolo Consoli/ Susanna Pasquali, Roma 2007, 405-419.

Verduchi, Patrizia, »Le terme con cosiddetto >heliocaminus « « in: Quaderni dell'Istituto di Topografia Antica della Università di Roma, VII (1975), 55-95.

Wenzel, Michael, Römische Gärten der Winckelmann-Zeit. Mit Beiträgen von B. Pawlitzki und D. Zobel-Klein, Stendal/Mainz 2006.

Winckelmann, Johann Joachim, Briefe, vol. 3 (1764-1768), ed. Hans Diepolder, Berlin 1956.

Winckelmann, Johann Joachim, Reflections on the Imitation of Greek Works in Painting and Sculpture, trans. Elfriede Heyer and Roger C. Norton, La Salle 1987.

Winckelmann, Johann Joachim, A History of the Art of Antiquity, trans. Harry Francis Mallgrave, introduction by Alex Potts, Los Angeles 2006.

Żmijewska, Artura, »Stanisław Kostka Potocki, critique du salon du Louvre«, in: Biuletyn Historii Sztuki, XXXIX, 1977, 344-353.

\section{Photographic Credits}

Fig. 1. Maciej Tarkowski, Mikołaj Baliszewski (3D Studio Max 8), 3D reconstruction of Stanislaus K. Potocki's Laurentine Villa. (Foto Maciej Tarkowski)

Fig. 2. Stanislaus K. Potocki, Vincenzo Brenna, Heliocaminus, coloured drawing, Warsaw, National Library (WAF 67, Rys. 5024). (Foto National Library)

Fig. 3. The so-called heliocaminus in Hadrian's Villa at Tivoli (Foto Jerzy Miziołek)

Fig. 4. Stanislaus K. Potocki, Vincenzo Brenna, Laurentina Villa, Statue of Hercules on the sea façade, coloured drawing, Warsaw, National Library, (detail of WAF 67, Rys. 5000). (Foto National Library)

Fig. 5. Domenico de Rossi, Hercules victor, etching in: Raccolte di statue antiche e moderne (1704).

Fig. 6. Domenico de Rossi, Hercules Farnese, etching in: Raccolte di statue antiche e moderne (1704).

Fig. 7. Stanislaus K. Potocki, Vincenzo Brenna, Franciszek Smuglewicz(?), Laurentina Villa, Triclinium, coloured drawing, Warsaw, National Library (WAF 67, Rys. 5.015).

Fig. 8. Artemis (Diana) from Gabii, engraving in François Perrier (1638).

Fig. 9. Dionysus with a panther, engraving in François Perrier (1638).

Fig. 10. Dionysus with a cup, engraving in François Perrier (1638).

Fig. 11. Hygeia (Salus), engraving in François Perrier (1638).

Fig. 12. Stanislaus K. Potocki, Giuseppe Manocchi, Laurentina Villa: frigidarium and unctorium, coloured drawing, Warsaw, National Library (WAF 67, Rys. 5.012).

Fig. 13. Stanislaus K. Potocki, Vincenzo Brenna, Decoration of the cenatio with the Dancing bacchic Satyr, Warsaw, National Library (WAF 68, Rys. 5028).

Fig. 14. Stanislaus K. Potocki, Giuseppe Manocchi, Project of the Museum of Fine Arts, coloured drawing, Warsaw, National Library (WAF 67, Rys. 5014).

Fig. 15. F. Tegazzo, K. Krzyżanowski, Gallery of Plaster Casts at the University of Warsaw, engraving, Warsaw, Library of the University of. 